\title{
ADDENDA AND CORRIGENDA
}

Shortly after the entry into force of the new editorial arrangements an unfortunate mishap took place, as a result of which pages 551-724 of the present issue were printed without the authors' final corrections. A list of corrections of those errors liable to cause misunderstanding is appended, and the Board asks the indulgence of the authors and readers of the articles concerned.

P. 565, 11 lines from the bottom : for " them by" read "by them ".

P. 600, line 11 : for نغ read

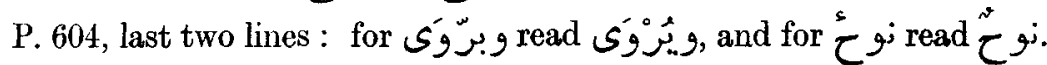

P. 620 , line 7 from the bottom : for "Suqām" read "Saqām".

P. 622, last line: for "Nawōh " read "Nuwāh".

P. 625, line 3 from the bottom : for " "Alid" read " Ali ".

P. 626, line 3 from the bottom : for " $a$ 'Wämihi" read " $A^{\text {'wämihi" }}$

P. 627, last line : for "Ermitage " read "Hermitage".

P. 629, last line : omit the reference to note 3 after "patterns".

P. 631, line 10 : for "church and not" read " church which are not".

P. 631, line 14: for "V. \& A." read " British".

P. 633, line 9: for "dated 650/1252, signed" read "dated 650/1252 and signed".

P. 633, line $17:$ for " $z \bar{a}$ timin is " read " $z \bar{a}$ liminn was".

P. 636, line 2: for "Thee" read "Thou".

P. 639, line 14 from the bottom : for "such on order " read "such an order".

P. 643, line 13: for " rüspig-zädak" read " rüspig-zädag".

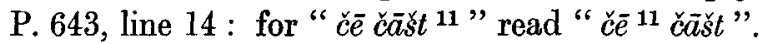

P. 645, line 1: for "kōdagän" read "kōdakän".

P. 646, line $11(=4 b)$ : for " $\bar{o} "$ read " $a u "$ ".

P. 647, note 6, line 2: for "Pers. bīsā mān" read "Pers. bì-sāmān".

P. 647, note 7: for " asprany" read " aspany".

P. 654, last line : for "bāste" read "bäśte".

P. 656, note 1, line 10: for "da-jvanyai" read "dajvanyai".

P. 661, line 1: for " $i-\check{s}$ " read " $-i \check{s}-"$.

P. 664, paragraph $36 d$ : add

For kunta-pipilika, the Tibetan text Derge $1.60 \mathrm{~b} 1$ has srog-chags grog-sbur. For the Jaina kunthu-pivilli, see J. Charpentier, Uttarädhyayanasūtra 36.138.

P. 664, line 4 from bottom: for "g $u$ " read "gu".

P. $665, \S 8$ : add

The Sanskrit Karmavākya (ed. A. C. Banerjee, Ind. Hist. Quart., 1949) was received after the article was set up. The doubtful text has tila-tusa"sesame straw", with which the Tib. Mūlasarvāstivāda text (Derge 1. 60 a 2) til-gyi phub-ma agrees. The Tumšuq text, however, remains unexplained. VOL. XIII. PART 3. 
In Khotan "sesame" was kumjsata. A similar word would be expected in

Tumšuq. Hence, the text will belong to a different school.

P. 667, line 1: for " zstau" read "astau".

P. 668, § IV, line 5: for " have gone" read " have come".

P. 673, line 18 : delete $64 c$.

P. 674, title: for "VARṆĀRHAVARNA STOTRA" read "VARNARHAVARNO BUDDHASTTOTRAM".

P. 675, stanza 6: for " so other dharmas do not" read " no other dharmas".

P. 678, line 18: for "aśakyastavo " read "'śakyastavo".

P. 681, stanza 9 : read " Hail to the Arhat".

P. 681, note 6: read "ätmabhāva".

P. 682, stanza 18: read "yathecchasparśaläbhine".

P. 682, note 3: for " $s u$ " read " so".

P. 683, stanza 25: for " none beside thee " read " none but thee".

P. 683, note 3 : read "prasrabdhi".

P. 686, stanza 43 : for "suddhaśaukșāya " read "śuddhaśaucyāya".

P. 686, stanza 44: for "muniśvaräya te namah" read "muníśàya namo 'stu te".

P. 688, stanza 54 : read "na tato 'st[y u]ttarataram".

P. 688, stanza 55 : for " apāharine " read "apahārinẹe".

P. 688, stanza 58: for " tvadrte" read "tvad rite".

P. 688 : delete footnote 18.

P. 694, stanza 8: read "dvātrimśallakșaṇavatā ".

P. 694, stanza 9 : add footnote "Read divākaro yathā".

P. 697, stanza 2 : for " thy knowledge" read " thy single knowledge".

P. 697, note 2: for "forms" read "terms".

P. 699, note 4 : read "abhinirvrtti".

P. 700, stanza 21: for "nāpnoti kaścid antaram" read " na kaścil labhate 'ntaram". 